\title{
Developing Elementary School Students' Honesty through Traditional Game of Balalasaman
}

\author{
Ririanti Rachmayanie; Akhmad Sugianto \\ Guidance and Counseling Major \\ University of Lambung Mangkurat \\ ririanti.bk@unlam.ac.id
}

\begin{abstract}
One of education purposes is to internalize character values which are emphasized on ethic that can be seen on individual's daily manner. Character can be said as a way to think and behave which becomes individual's characteristic for working together, whether in family scope, society, nation and country. One of those character values is honesty. Honesty is a basic key in living together and the key to create a dignified nation. The aim of this writing is to give stimulus to the readers to do a research using this title. Therefore, it can prove the study of literature. The value of honesty in elementary school can be developed through traditional game technique called balalasaman. Through that technique, it is expected to develop students' honesty and train elemetary school students' motoric skills.
\end{abstract}

Keywords: Balalasaman Game, Elemtary School Students, Honesty Character

\section{PREFACE}

A high level of education can be said as a starting point of a nation prosperity. Education changes human to be a virtuous man and makes human has a good moral. Therefore, goverment should provide education with good quality in order to achieve human development goal (Nurokhim, 2007). Considering on UU Sisdiknas year 2003, an ideal education not only creates intellegent individual, but also has a good character. Therefore, education can produce generations that have glorious and religious values. Education has important role for individual's life and development, including elementary school students. Ki Hajar Dewantara (in Dahar, 2006) stated that "Education is meant to developed students as human (individual) and as member of society (social). Suharjo also said that "Education plays an important role in developing physical aspect, intellectual, religious, moral, social, emotional, knowldege and students' experience." Related to the development of all aspects including moral intellectual aspect, emotional, and religious can build honesty character. However, it takes continous exercise through some habituation processes. Through that process, the habit of character can be created. Not only that, the habit also merges with how someone behaves everyday. This is suitable with the Graduation Standard (GS) based on 2013 curriculum which emphasized that the result of learning is character building that is followed with intellegence and skills (Kemendiknas, 2013).

Nowadays, we have seen many phenomena that indicated the decrease of moral values in Indonesia education. This can be seen as a warning that makes all parties see an important synergy for developing character in education. There are many evidences that showed the application of character education at school that helps creating better school culture, makes the students' feel safer, and helps them to concentrate in their studies. Therefore, their achievement is increasing.

In order to prepare national character, there are some efforts need to be done, such as, building values in students and also create an education environmental where every individual can live up his freedom, as a condition to a mature moral living. Preparing national character is a pedagogy which purposes to make every individual living up his individuality and be able to appreciate freedom. Therefore, the individual can grow as a responsible citizen and has moral integrity on living together with others in the world (Koesoema, 2007).

Demoralization that happened recenlty was increasing, especially among children and teenagers. Some of the signs often appear in newspaper and even television. For instance, many children and teenagers nowadays are not honest and respective to their parents or teachers.

Honesty is a character that can eradicate this country from corruption, collusion, and nepotism. Honesty in Indonesian dictionary is a quality of being honest, not cheating. In other word, honest can be said as "there is similarity between what someone says and what really happens", or "as it is" (Kesuma, 2011). Honesty or shiddiq (in Arabic) is a true reality, whether in words, behaviour, or actions; in outside and inside himself. Honesty is a strong belief system, stable in speaking, acting, and saying what is in the heart (Aqib, 2011).

This concerns has motivated the writer to observe the problem about honesty in education. Everyone has his own character, but this character has not developed optimally. The writer tries to offer an effort about the realization of honesty in education through a group guidance service using balalasaman game technique to help developing students' honesty. The result of this research showed that traditional child game can stimulate children in developing group work, hard 
work, interaction, empathy, and appreciate others to behave honestly (Kurniati, 2011:13).

Traditional child game which can develop students' honesty is balalasaman game. Balalasaman is one of traditional games from Banjar in South Kalimantan. Balalasaman is usually played by children, teenagers even adults. The values that exist in this game are growing and developing honesty. Therefore, it can be understood that traditional game called balalasaman can develop honesty on students (Yunus and Soenarto, 1981:36).

\section{METHOD}

The method that is used in this article is a literature review method. Literature review method done through reading some relevant references, for instance books, e-books, journals, and articles.

\section{Relevant Research}

Kurniati (2013) asserts that the result of this research showed that traditional child game could stimulate children in developing group work, hard work, interaction, empathy, and appriciate others to behave honestly.

Yunus and Soenarto (1981) state that traditional child game which could develop children's honesty was balalasaman game. Balalasaman is one of traditional game from Banjar in South Kalimantan. This game is usually played by children, teenagers and adults. The values that exist in balalasaman game are growing and developing honesty. Therefore, it can be understood that traditional game of "balalasaman" can develop students' honesty.

\section{DISCUSSION}

\section{Group Guidance Service}

Group Guidance is a guidance service that is given in groups. Group guidance refers to activities which focuses on supplying information or experiences through group activities which is planned and organized

(Gibson dan Mitchel, 2011:275). Group guidance service helps students in developing individual, social relationship ability, teaching and learning, career/position, making decisions and doing certain activities through group dynamic. Group guidance service has functions and purposes to give information and to develop individual's potency and also useful to prevent obstacles for students.

Group guidance service in this journal was held with small groups consist of 2-6 students using balogo game technique. In this game, there was one personas leader of the group. The leader of the group was trained counselor/ Counseling Guidance Teacher. Therefore, they had authority to hold the guidance and counseling (Tohirin, 2011:171).

Steps in group guidance service are divided into four steps, they are:

Step I: Forming stage
Step II: Transfer stage

Step III : Group task activity

Step IV : EndingCharacter of Honesty

Honest can be defined as admitting, saying or giving information which is true or real

(Hendra, 2010). In Indonesian dictionary, honest means not lying, heartfelt, and trust words, and not likely to cheat. If someone says things that is not true or did not admit something like as it is, then that person can be said as dishonest, deceive, disaffirm, lying, and so on (KBBI, 1991). Honesty is character that means brave enough to say personal belief which shows who he is.

Based on the definition above, we can conclude that definition of honesty will be reflected in behaviour that is followed with sincerety, speaking the truth, acting based on the fact. Therefore, honesty is one of elements of spiritual power, good moral, and also personality.

The main purpose of education is to form honesty, because honesty is basic thing in living together and the key to succes. Through honesty, people can learn, comprehend, and understand about balance-harmony. Honesty is applied towards individual role, honest towards right and responsibility, honest towards existed arrangement, honest in thinking, behaving and acting. Deceit is form of dishonesty which often happens in life. If the honesty gone away, the chaos and disharmony would take place. All we have left is just manipulation on attacking someone else's rights, oppression and so on.

The value of honesty is one among Islamic moral values. The value of honesty which is based on religious values is parallel to moral ethic values which is applicable generally. The development of those values is believed to be very effective through education and the result will be reflected in social life. This is an ideal dream from education world as a basic to learn about honesty.

The process of building the values of honesty on students cannot be taught theoretically, such as memorize definitions or experts' opinion. The building of honesty values is demanding social life arangement which realize those values. Good exemple from parents and teachers, will give students the right modelling to reflect the personality in their lives. Without good exemple (in this case is honesty) on parents' and teachers' personality, the students will lose their public figures that can bring them to be a man of character.

A wise man once said that honesty starts from homes and schools. This indicates that the role of parents and teachers are significantly important in building the values of honesty. To discuss it further, we can use historical approach, so it will be clearer about the event and education situation that has hapenned.

\section{Balalasaman Game}

Balalasaman game was taken from root samsaman which had prefix $b a$-. This game is usually played by boys and girls at the age of elementary school. Balalasaman game usually takes place on flat and dry yard.

Balalasaman game is using a simple playing field made on the ground by making rectangular lines of large $\mathrm{T}$ letters and above them combined with a circle 
called the mountains. The player usually consists of 2 to 6 people who have a flat-shaped rock with a diameter of about $5 \mathrm{~cm}$ so-called undas. It can also be used from board pieces of $5 \times 5 \mathrm{~cm}$. The game board is illustrated as follows.

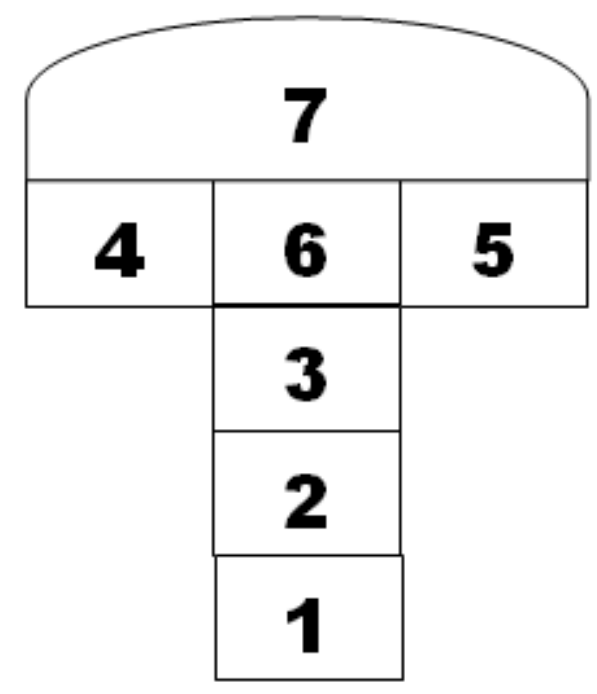

Picture 1. The area of balalasaman game

The player who gets the first turn is done with basiun, for example, there are $\mathrm{A}$ and $\mathrm{B}$ and $\mathrm{A}$ wins basiun, then A deserves to play first. A begins to stand near the box 1 , facing the linelalasaman, he throws the undasshould not be trodden. A immediately jumps into box 2 when A stepped on the line area then declared lost and moves to the next player. A jumps with one foot to provided box called "ba-inting-inting". Some of the things that can make a player declare dead are:

a. Players use two legs that should be with one leg only, namely bainting-inting.

b. The game was stomped on the dividing line.

c. Game trampled on the box that has the undas.

d. Players stepped on the box that has become home.

e. The cast throws the downline down the line.

f. The player throws the undes dropped into another box that should be aimed.

The Balalasaman game can train motor skills, especially in maintaining a balance during the game. In addition, the game can also train intelligence in crafting strategies and organizing strategies, especially in determining which houses will be owned. Furthermore, this game can foster the spirit of competition and the soul of sportsmanship in the game. Thus, this game can foster honesty, create joy and tighten friendship (Wahyu et al, 2015).
The establishment of the character of honesty in the school environment will be realized through cooperation of the role of school stakeholders, such as the role of teacher guidance and counseling. One of the guidance and counseling services that can be provided to students to improve hard work is a group guidance service with balalasaman game techniques. Thebalalasaman game which played in the team that consists of 2-3 people using the undas.

The values built in the game of balalasaman are motor skills, hard work, sportsmanship and honesty. The value of motor skills is reflected by the player in performing bainting-intingan. The value of hard work is reflected in the players' efforts to jump over the box that has undas. The value of honesty is reflected when the player throws or steps on the line of the game arena. The value of sportsmanship is reflected in the willingness of players who lose.

\section{SUGGESTION}

The author of this journal is expected to provide a stimulus for the readers to conduct research using this title. The purpose is to prove the results of the literature studied.

\section{BIBLIOGRAPHY}

Aqib, Z. (2011). Character Education Building Positive Behavior of Nation Children. Bandung: Yramawidya

Dahar, B. (2007). Theories of Learning and Learning. Bandung: Rineka Cipta.

Kemendiknas. (2013). 2013 Curriculum for Primary Schools. Jakarta: Depdiknas.

Kesuma, D., \& Permana, J. (2011). Character Education Theory and Practice Study in School. Bandung PT Remaja Rosdakarya Off Set.

Koesoema. (2007). Character Education Towards a Childhood Education Strategy in the Global Age. Jakarta: PT Grasindo.

Kurniati, E. (2011). Guidance Program for Child Social Skills Development Through Traditional Games: Journal of Innavtio, 10 (1). 151-166.

Nurokhim, B. (2007). Building Character and Nation's Character Through Education is Absolutely Necessary. Jakarta: Rajawali Pers.

Wahyu, et al. (2015). Contextual Analysis of Traditional Knowledge and Expression of Traditional Culture Based on Local Content in South Kalimantan. South Kalimantan: Belief in God Almighty and Tradition Directorate General of Culture Ministry of Education and Culture of the Republic of Indonesia.

Yunus \& Soenarto. (1981). People's Games Area of South Kalimantan: Gusjigang Counseling Journal, 10 (1). ISSN 2460-1187.

\section{CLOSING}

\section{Conclusion}

